\title{
Gene Symbol
}

National Cancer Institute

\section{Source}

National Cancer Institute. Gene Symbol. NCI Thesaurus. Code C43568.

A unique gene name approved by an org anism specific nomenclature committee. 